\title{
Roger Bastide e a Identidade Nagocêntrica
}

\author{
Arilson S. deOlivera ${ }^{1}$
}

Resumo: 0 artigo debate a produção de Roger Bastide sobre o Candomblé no Brasil tendo em vista as críticas feitas ao longo do tempo à obra deste sociólogo e antropólogo. Procura, assim, pontuar os avanços nos estudos sobre as religiões afro-brasileiras a partir do levantamento de discussão bibliográfica e seus desdobramentos na obra de Bastide.

Palavras-Chave: Roger Bastide, Identidade, Nagocentrismo.

Abstract: The article aims at to debate the production of Roger Bastide on the Candomble in Brazil in view of the critical ones made throughout the time to the workmanship of this sociologist and anthropologist. Search, thus, to pointier the advances in the studies on the religions afro-Brazilians from the survey of bibliographical quarrel and its unfolding in the workmanship of Bastide.

Key-words: Roger Bastide, Identity, Nagocentrism.

\begin{abstract}
A té minha miteserei reconhecidb a todas as Mães de Santo que me trataram com um filhobramo, às Jœanas deOgumeàs Jœanas deIemanjá, quecompreenderamminha ânia par novos alimentos alturais e, com aqude sau caracteństico dom superior de intuição, pressentiram que meu pensamento cartesiano não supataiia as novas subsânias como verdadkiros alimetos (istoé não poderiamser por nimabsorvidos comb aconteee naqualas relaçães puramente dentíficas que pemaneem na supefíie das cisas, não se meamoroseandb em experiênias vitais as únicas fontes de compreensão), sem que antes fossem explicadas para tomarem assimiláves, como o faria a nãeneya queerdava, em suas nãos fatigadas, a comida destinada aos sas nê̂s, fazendb bodinhas, depis colocadas afetuosamente na boquinha dies Para mim meu conheimento da África conserva toob o sabor dessa temura matemal, aquide odr das mãos neyras cainhnosas aquala paciênia infinita ma deta de suas "sabedbrias". Tere me conservadb dignos dlas? (Roger Bastide, EstudosAfroBrasileinos)
\end{abstract}

A religião afro-brasileira, genericamente denominada Candomblé, a qual possui outras denominações ou variantes - dependendo do contexto histórico ou africano no qual se insere - em diferentes regiões do Brasi, como, por exemplo, Xangô no Recife, Macumba e Umbanda no Rio de Janeiro e em São Paulo etc., é provavelmente o mais notável patrimônio sociocultural edificado pelo negro na América Latina. A terminologia

\footnotetext{
${ }^{1}$ Bacharel em História, mestre em Sociologia e doutorando em História Social pela Universidade de São Paulo (USP). Tem experiência na área de História e Sociologia, com ênfase em História Intelectual, Sociologia da Religião e História da Religião. Foi mestrando do Dr. Lísias Negrão, um dos maiores especialistas em Candomblé do Brasil.

2 A estrutura do candomblé assenta segundo Magnani (1986) no babalaô, o qual interpreta e adivinha através do jogo de búzios ou do colar de Ifá; no babalossaim (encarregado das ervas e folhas sagradas) e no babalorixá, ou ialorixá, se for mulher (que orienta o ritual e determina o comportamento de várias figuras relevantes do culto, entre eles: os abiãs, os candidatos à iniciação; os iaôs, os já iniciados; os ekedis, mulheres que ajudam no culto; a iabassê, responsável pelas comidas rituais; os ogãs, homens que ajudam no culto, entre os quais se incluem os alabês, que tocam os atabaques, e o axogum, o sacrificador ritual etc.). A "casa", o ilê, do babalaô, é o centro da família e pode funcionar como residência fixa para alguns dos seus membros (MAGNANI, 1986: 39). Pelo contrário, na umbanda (que surge e se desenvolve num contexto urbano e industrial) o local de culto deixa de ser o núcleo de uma comunidade e passa a ter horário de funcionamento, enquadrado por um vasto e complexo mundo de federações, com uma estrutura burocrática assente num estatuto. A hierarquia espiritual é menos complexa que a do candomblé: pai ou mãe-de-santo ou madrinha, pai e mãe pequena, auxiliares de culto (cambonos e tocadores de atabaque) e filhos-de-santo, ou de fé, que constituem o corpo de médiuns.
} 
"candomblé" provém da fusão de duas palavras de orígenes distintas: Candonbe(de origem bantu) e Ilé(de origen yorubá).

Esse patrimônio ganha extraordinária dimensão e significado especial porque não é apenas um complexo sistema de crenças estruturado para servir unicamente às necessidades religiosas de quantos se ligam ao candomblé atıvés da iniciação, nos diferentes estágios da hierarquia inclusiva, ou daqueles que simplesmente participam dos cultos e das cerimônias públicas que ali se realizam. Isto bastaria para uma situação ao mesmo nível de importância e cmplexidade litúrgica às chamadas grandes religiões do mundo, posto que o candomblé elaborou, como as demais, suas respostas teológicas para as inquietações fundamentais do homem: com base nas culturas milenares africanas sobre 0 universo, a natureza das coisas e as coisas da natureza.

Constitui o candomblé, portanto, uma comunidade de natureza altemativa que permite aos seus membros um esilo de vida bastante diferenciado do que se tem na sociedade mais ampla.

O candomblé juntamente com todos os sistemas religiosos afros estão, em última instância, profundamente impregnados de forças civilizatórias negro-africanas (BRAGA, 1995: 20), que realizam no corsciente coletivo da população negro-brasileira, um sentimento profundo de identidade cultural ${ }^{3}$ que engendra, por sua vez, e de maneira não pouco perceptível, os alicerces primeiros da noção de etnicidade, qualquer que seja 0 horizonte semântico que se empreste a esta mágica palavra, e esta ferramenta de trabalho da comunidade negra politicamente organizada, na projeção do ideal de reconhecimento das diferenças que identificam e qualificam o negro na sociedade.

Na obra "Ancestralidade Afro-Brasileira", quando Braga trata do problema do ajustamento do candomblé à nova realidade social, que possiblitou a criação de mecanismos de adaptação e de ntegração sem, contudo, se afætar drasticamente da tradição e dos elementos essenciais de origem, afirma enfaticamente:

O candomblé sintetiza diferentes valores culturais, ao formar complexa organização sócio-religiosa, que não encontra paralelo em nenhuma das

\footnotetext{
${ }^{3}$ No plano religioso, a introjeção de uma identidade profunda que associa definitivamente 0 iniciando à maneira de agir e sentir, segundo os padrões da religião afro-brasileira, é realizada durante o período de reclusão conventual. Em um dos segmentos da liturgia apropriada, o sacerdote, através do jogo de búzios, lhe revela o Odu o caminho, o destino, isto é, aquele conjunto de normas que vão de certa maneira reestruturar a vida do novo acólito em função de sua nova condição de iniciado. É um dos momentos mais significativos do ritual de iniciação, se não o mais importante, em particular, para as iniciandas. 0 sacerdote, após a sessão divinatória, recita para ela um mito que se refere ao Odu revelado. A partir do texto mítico, ele indica à inicianda certos aspectos de sua vida, os traços de seu caráter e as normas de comportamento que devem orientar sua existência a partir desse dia. (Ver: BRAGA, 1980: 113-122).
} 
sociedades tradicionais africanas envolvidas pelo tráfico de escravos para o Brasil. De certa maneira, têm sido decepcionantes os resultados das viagens realizadas por pais e mães-de-santo as diferentes regiões da África, ao se darem conta de que não existe nenhum organismo religioso, cuja estrutura se aproxime ou sirva de modelo às suas próprias casas de culto às divindades que constituem o complexo panteão de origem africana e afro-brasileira. (BRAGA, 1992: 142).

Em suma, candomblé é, na essêrcia, uma comunidade detentora de uma diversificada herança cultural, onde se mesclam elementos provenientes, sobretudo, da África Ocidental. E no Brasil, por força das relações de contato a que estiveram permanentemente submetidos, afirma Braga, integraram-se outros tantos componentes religiosos de procedência igualmente variada. Por sua dinâmica interna e pelo sentido de religiosidade que ali se constata em todos os instantes da vida grupal, ${ }^{4}$ o Candomblé é gerador constante de valores éticos e comportamentais que enriquecem e imprimem sua marca no patrimônio cultural do país. E, diferentemente de outras formações religiosas, é uma fonte permanente de gestação, de valores e de promoção sociocultural, plasmando os sustentáculos da auto-estima do negro numa sociedade historicamente hostil em aceitá-lo e tê-lo como elemento vital de sua formação cultural e social.

Neste sentido, o Candomblé deve ser entendido como um conjunto mais amplo que envolve, para além dos compromissos religiosos, uma filosofia de vida, uma maneira especial de interação do homem consigo mesmo, com a natureza, com o seu passado, com sua origem e sua especificidade cultural, sem perder de vista suas relações profundas com outros segmentos sociais, igualmente comprometidos com o processo que elabora e particulariza a formação da sociedade brasileira. E um dos pensadores que irá ampliar e restaurar nosso olhar sobre esse pensar religioso, será Roger Bastide, um francês com a mente e os pés no Brasil e na África.

\section{Roger Bastide em tomo da religião afro-brasileira}

O encontro de Bastide com a África em territóno brasileiro coincide com sua primeira viagem ao Nordeste, em 1944. A viagem, segundo o seu relato, representou a descoberta do Brasil místico, "onde sopra o espírito" (BASTIDE, 1945: 37). Assim, é a África que se impõe ao observador na medida em que "[...] penetra pelos ouvidos, pelo nariz e pela boca, bate no estômago, impõe seu ritmo ao corpo e ao espírito", obrigando-o

2 Parece estranho, e até mesmo profano, segundo Braga, que para muitos que não estão familiarizados com a vida religiosa afro-brasileira, tomam-nas como meras expressões do exótico. 
a passar do "estudo da mística das pedras e da madeira talhada" para a "religião dos pretos" (Ibid., 28).

Os primeiros contatos com o mundo do candomblé, na segunda metade da década de 1940, permitem a Bastide delinear um rol de preocupações que o acompanhará em seus escritos posteriores: a estrutura existente entre crise mística e crise histérica, as distinções entre candomblé e umbanda. Mas o que de fato irá causar forte impressão neste momento inicial de descoberta da África é a estética afro-brasileira, o "espetáculo maravilhoso", "encantador", a festa. Bastide concentra boa parte de seu relato descrevendo o movimento e a alegria do adepto preparando-se para os festejos e celebrações, a "loucura divina" que toma conta das ruas, a sensualidade das danças e dos ritmos. Neste relato de viagens, a presença da África no Brasil se revela através de uma dimensão eminentemente sensível: imagens e sons, arquitetura e tipos físicos.

A observação dos rituais, o depoimento dos integrantes dos cultos e a literatura disponível permitem a Bastide registrar sua primeira apreensão desse universo místico: "poderia acreditar que me encontrava em plena África" (BASTIDE, 1945: 80). O candomblé, com sua filosofia e seus ritos, conformaria uma comunidade mística no interior da comunidade baiana e uma comunidade africana no seio da sociedade brasileira. 0 candomblé é descrito nesse momento como um mundo à parte, uma sobrevivência nítida da África no Brasil (Ibid., 108).

Os trabalhos realizados no final da década de 1950 traduzem um esforço de entrada mais profunda no mundo africano entrevisto em 1944. Em "As Religiões Africanas no Brasil" (1960), Bastide vai lançar as bases para a compreensão do sincretismo em sua versão histórica e em suas formas atuais; em "O Candomblé da Bahia: rito nagô" (1958), volta 0 seu olhar para a estrutura africana menos contaminada pela sociedade brasileira abrangente, em um trabalho de forte inclinação etnográfica Aí, afirma Bastide, não interessa a busca das origens africanas ou o sincretismo. "Estudaremos o candomblé como realidade autônoma” (BASTIDE, 1958: 10).

Através da religião africana, 0 intérprete passa por uma espécie de aprendizado da África e uma espécie de pedagogia do mundo africano, que pemite a passagem da vida profana à vida mística:

É a 'escola da selva' transplantada da África para a cidade da Bahia. 0 termo ' escola' é bastante exato; um de meus informantes comparava a estada da candidata na aliaché à escola primária, dizendo que a instrução prossegue pela vida toda; se quisermos atingir os graus mais elevados da hierarquia, é preciso passar em seguida pela escola secundária [...] (Ibid., 39). 
Em seu esforço de descrição de um mundo particular de representações coletivas, Bastide elege como interlocutores preferenciais os africanistas, brasileiros e franceses. Afinal, é como africanista que ele se dirige agora, comprometido com a elaboração de uma antropologia/ sociologia africana. Logo na abertura do volume, repassa sobre as religiões africanas no país, localizando as contribuições de Nina Rodrigues, Manuel Querino, Arthur Ramos, Édison Carneiro, Herskovits, Pierre Verger, dentre outros, para a compreensão do mundo africano entre os brasileiros. Mas a maior inspiração teórica desse trabalho é a pesquisa de Marcel Griaule e as suas formulações sobre o pensamento africano como um pensamento culto. Apoiado nas teses do africanista sobre os Dogons, Bastide mergulha na elucidação da "metafísica nagô". Para tanto, percorre cada rito, cada cerimônia, cada possessão, cada iniciação.

Com efeito, uma série de fatos mostra a persistência no Brasil de fragmentos da metafísica esboçada por O gotemmêli em suas conversas com Griaule: a dualidade da divindade primordial, a desordem se introduzindo no mundo devido à perda desta dualidade e à distinção dos sexos, a importância dos números, do ferreiro, do arqueiro, do carneiro, dos gêmeos [...] (BASTIDE, 1958: 226).

Para Bastide, o candomblé de procedência nagô, onde $\$$ observa a menor incidência de sincretismo, é formado por ele como o exemplo mais fidedigno do mundo africano, descrito como sistema de partição específico, "pedaços da África plantados em pleno coração do Brasil" (Ibid, 67). Assim, o candomblé atestaria a segregação de estruturas a partir das representações místicas. 0 social neste caso - entendido como rede de sociabilidade e como sistema ético moral - seria fruto da matéria mística, nos termos de Graule (Ibid., 109). E, segundo Bastide, bastaria um pouco de amor, amizade ou respeito para que o pesquisador fosse finalmente admitido a penetrar nesse mundo mítico e místico, podendo assim - e só assim - compreender o significado simbólico das cerimônias participantes (Idem., 1985: 334).

No entanto, as análises de Bastide sobre as religiões afro-brasileiras foram (e ainda são) objetos de fortes controvérsias. ${ }^{5}$ Foram criticadas: a etnografia por ele realizada, a

50 que não anula a opinião de 0 rdep Serra, o qual afirma que a atuação de Bastide no Brasil, como pesquisador dos cultos de origem africana "ocupou a maior parte de sua vida e teve importância capital para a consolidação dos estudos afro-brasileiros: sua obra constitui, até hoje, o mais profundo ensaio de interpretação sinótica das religiões negras do país" (SERRA, 1995: 129). 
adoção de uma perspectiva marxista, a noção de princípio de corte, ${ }^{6}$ a imprecisão de suas afirmações etc.

Yvonne Maggie em "Guerra de O rixá" (1975), por exemplo, ao realizar um estudo de caso sobre um terreiro de umbanda no Rio de Janeiro, explica o seu desejo de rompimento em relação aos estudos africanistas recentes, na medida em que estes evitaram uma análise apurada do sincretismo, optando pela busca da ongem dos traços culturais. Estes traços, segundo Maggie, foram invariavelmente associados a um maior ou menor grau de evolução cultural: os traços de origem africana, relacionados ao primitivismo, à magia, às camadas populares e ao "rural, emocional, não racional", enquanto os espíritas, elevados ao patamar superior, mais adequados ao padrão racional e civilizado da vida urbana. Tal "raciocínio teleob́gico" que procurava os traços e suas origens para a explicação do presente, de acordo com ela, atravessou os estudos sobre religiões afrobrasileiras de Nina Rodrigues, no final do século XIX, a Candido Procópio, na década de 1960 (ALVES VELHO, 1975: 12-13).

Na visão de Lísias Negrão (1996), a iniciação formal de Bastide no candomblé, é a razão pela qual o candomblé pæssa a ser "o paradigma da religião Afro-Brasileira, em relação ao qual os demais cultos de origem africana passam a ser comparados e aferidos em seu valor" (NEGRÃO, 1986: 55).

Negrão adianta afirma que a umbanda é sem dúvida alguma a modalidade de religião afro-brasileira mais praticada em todo o Brasil. Embora sua consolidação tenha se dado nas cidades do Sudeste (ao contrário do candomblé, o qual foi mais desenvolvido e acentuado nas cidades nordestinas), atualmente a maioria das localidades do território nacional conta com pelo menos um terreiro de umbanda a divubar sua mensagem religiosa, as características de seu rico e complexo panteão e sua visão de mundo fortemente magicizada - e aqui ele está pesando em Weber.

\footnotetext{
${ }^{6}$ No qual ele estuda, por um lado, as condutas diferenciadas dos Afro-brasileiros no quadro religioso do Candombée, por outro lado, na vida civil e profissional. Mas nos parece que no "princípio do corte", assim como nos textos que compõem essa obra, o autor pressupõe uma permanência e uma unidade do sujeito, suscetível de "justapor" dois universos que se "correspondem", o que permite "a simultaneidade dos comportamentos diferentes sem conflito interior". Substituindo as "correspondências" entre os "compartimentos do real" àquilo que havia sido visto antes dele como alternativas exclusivas (Lévy-Bruhl) ou modalidades possíveis podendo ser reabsorvidas dentro de uma ordem superior (D urkheim e depois LéviStrauss), Bastide não permanece tributário de um pensamento que atribui primazia ao espaço em detrimento do tempo. Ele nos deixa bastante desprovidos para pensar a questão da intermitência (das línguas, das linguagens, dos pensamentos e dos sentimentos) do sujeito em seu devir.
} 
Negrão afirma que "Bastide considerava a macumba uma express̃o degradada, anômica, em que predominava elementos mágicos descontextualizados e sem respaldo coletivo". Acrescentando que procura contraditálo ao demonstrar a

existência desde as primeiras décadas do século de grupos organizados e atribuindo a interpretação do autor a pressupostos teóricos e lógicos insatisfatórios e ao método equivocado de sua abordagem (Idem, 1996: 37).

No entanto, em outro momento, Negrão afirmará que, recentemente, os trabalhos de Bastide foram submetidos à críticas, às vezes severas demais e até precipitadas, no tocante ao conhecimento fragmentário de sua obra, "quando não a preconceitos teóricos" (NEGRÃO, 1986: 47).

Por outro lado, para Édison Carneiro, o sincretismo representa "degeneração" sim, mas "degeneração" da africanidade, pois não foi somente com o catolicismo que se verificou a obra do sincretismo na Bahia. Mas foi o catolicismo a influência predominante. E, já agora, há mais uma modalidade inesperada de sincretismo, - a sessão de caboclo, onde predominam as práticas espíitas sobre o ritual fetichista. Assim, agindo e reagindo, a mitologia negra vai se degradando, se decompondo, se incorporando ao folclore nacional. (CARNEIRO 1981b: 97).

Carneiro afirma que as etnias "bantus" seriam muito mais suscetíveis a esse processo de "degeneração" do que a yorubá. Pois ele sustentava a tese de que a autêntica religião negra teria sido trazida para o Brasil por gente de origem yorubá (nagô ou queto); que essa religião só em alguns poucos terreiros de Salvador manteria sua pureza original; e que ela só fazia "degenerar", na medida que se propagam em centros de outras etnias ou, de maneira mais ampla, na sociedade nacional.

Era como se o "arianismo" de Nina Rodrigues fosse transportado para o povo nagô, os únicos criadores de tudo que tem valor em matéria de religião afro-brasileira. Não obstante, o conceito de modelo nagô, pureza nagô ou, literalmente, de "rito nagô", em Bastide, deriva diretamente de Carneiro. Bastide também não nega a realidade do sincretismo, ao qual, aliás, dedica todo um capítulo em "As religiões Africanas no Brasil". Mas, partindo da noção de pureza que toma emprestada a Carnèro, Bastide, não sem ambigüidades, aliás, declara que a miscigenação africaniza os brancos, da mesma forma que desafricaniza 0 negro; a integração numa classe, que é a forma que toma a integração do negro à sociedade global, não trunca por completo as religiões africanas, mas induz 0 sincretismo ao seu máximo, desnaturando-as e corrompendo-as. 
Na verdade, quaisquer que sejam as influências européias que possam contribuir para explicar a adoção por Bastide do paradigma da memória africana, ou da memória nagô, cuja pureza é comprometida pelo contato com a sociedade nacional, podemos imediatamente reconhecer, na concepção do sincretismo como degeneração ou degradação, sua dívida com relação a Cameiro.

Já o trabalho de Beatriz Dantas, "Vovó Nagô e Papai Branco" (1988) desenvolve esse argumento crítico mediante a realização de um trabalho sistemático de avaliação dos estudos sobre religiões afro-brasileiras. A autora defende a idéia que dessa busca incessante de africanismos emerge a valorização da pureza dos candomblés e o "modelo nagô". D esde Nina Rodrigues até Bastide, diz ela, os intelectuais transformaram a categoria nativa da "pureza do nagô", símbolo da autenticidade africana, em categoria analítica, contribuindo através do modelo jejênagô para a cristalização de traços culturais que passam a ser tomados como expressão máxima de africanidade, através das quais se apresentará 0 africano .

Obcecados pelo rastreamento das sobrevivências africanas e elegendo a tradição nagô como exemplo máximo da africanidade, os antropólogos tenderam a opor, segundo ela, o candomblé nagô, mais "puro", à umbanda e à macumba, aos candomblés de caboclo e de angola, considerados "degenerados", "deturpados", "sobrevivências religiosas menos interessantes" (Ibid., 21). Endossando o corte explicativo por Maggie, e reafirmado pelos trabalhos de Peter Fry (1982) e outros, a autora aponta o tavo romântico dessas abordagens - as quais valorizam o africano como selo da nacionalidade, ou pelo menos, como traço distintivo da região Nordeste brasileira - e a fragilidade analítica e mesmo descritiva da categoria de "pureza nagô". Afinal, nem todos os terreiros nagôs possuem um acordo a respeito do que seja a tal herança africana autêntica, conclui.

O comentário de Duglas Monteiro às "Religiões Africanas no Brasil", embora siga outra linha argumentativa, recoloca a questão da "pureza" e a cisão estabelecida por Bastide entre religião (pura) e magia (sincrética), ou entre umbanda e candomblé. Tomando como referência o diálogo da obra com o marxismo (as relações entre infra e superestrutura e a visão da religião como ideologia), Monteiro localiza o centro de sua crítica na concepção implícita que sustentaria, em sua opinião, a análise de Bastide: a idéia de "sagrado autêntico". Operando com este modelo, que traduziria uma articulação perfeita entre valores religiosos e situações sociais que lhes dão sustentação, é quando Bastide coloca em oposição uma "religião autêntica" (cujo suporte empírico é o candomblé) à uma "religião- 
ideologia" (a qual tem na umbanda o seu exemplo mais acabado) (MONTEIRO. 1978: 1124).

Peter Fry, que já havia feito restrições às teses de Bastide em artigos anteriores, desenvolve-as em 1986. "Galius africanus est ou como Bastide se tornou africano no Brasil", por exemplo, parte do dilema identitário de Bastide, tornado afro-brasileiro, para mostrar como o pesquisador nada disse de novo em relação aos estudos anteriores, na medida em que consolidou a positivação do candomblé baiano, em sua "autenticidade nagô" e a distinção entre candomblé e macumba (SIMSO N, 1986: 31-46). Posteriormente, volta à obra de Bastide, registrando a sua perplexidade diante dos partidos teóricos opostos por ele tomados: simultaneamente herdeiro de uma tradição romântica que remonta a Nina Rodrigues, e que perseguiu a África no Brasil, e seu opositor, já que na década de 1950 encabeçou, com Florestan Fernandes, a pesquisa sobre relações raciais, patrocinadas pela UNESCO.

Para Lucilene Reginaldo, com Bastide (e outros) restou apenas a magia aos povos bantos, o que caracterizou uma "hierarquia étnica", também presentes em Cuba e no Haiti (REGINALDO, 2004: 13). Segundo Lucilene, "não apenas Bastide, mas muitos de seus contemporâneos, antropólogos e sociólogos, continuam reproduzindo estes estereótipos como foros de verdade.

As observações de Arthur Ramos (1940) comparando a pobreza da religião banto no sudeste com as manifestações religiosas dos nagôs do nordeste, e as de Belfort de Mattos (1938), apontando para o total pauperismo da macumba paulista, foram posteriormente incorporadas, ao lado de outras referências, às interpretações de Bastide.

Todavia, seria difícil sustentar continuidades teóricas que unissem Bastide aos seus predecessores nos estudos das religiões afro-brasileiras. Bastide, seja pela sua extrema capacidade de manipular dados provenientes das mais variadas fontes geográficas e literárias, ou de produzir sínteses originais teóricas, situa-se, como nenhum outro, entre os pesquisadores do tema.

Seus pressupostos teóricos surgem de variadas fontes, mas, sobretudo, sempre focada na tradição francesa: na teoria das classificações primitivas de Durkheim e Mauss, na qual ele se apóia para explicar o sincretismo; com Georges Gurvitch ele se inspira na "sociologia em profundidade", a qual o direciona para os problemas da aculturação afrobrasileira, em termos das múltiplas referências que perfazem a universalidade do fenômeno de contato entre as culturas. Por outro lado, será no tratamento dos temas tão caros à 
tradição afro-brasileira que será possível traçar os liames que unem Bastide aos seus predecessores.

Para Bastide, o estabelecimento do regime escravista e sua transição ao regime capitalista - com a característica de trabahlo "livre" - promoveu efeitos não só na sociedade brasileira, mas nas mentalidades dos adeptos das religiões de origem africanas.

De acordo com o francês, as religiões de origem africana puderam se organizar e acomodar nas capitais litorâneas do nordeste, pois estavam mergulhadas, segundo seu critério teórico marxista, em um mundo ainda permealo por valores tradicionais (comunitários ou précapitalistas) - aproximados, portanto, daqueles valores que predominaram nos locais de origem dessas religiões na África Todavia, a infraestrutura que sustentava esses valores fora destruída por ocasião do tráfico de escravos e através das peculiaridades do sistema escravocrata brasileiro que aqui separou etnias, coibiu a formação de famílias e não permitiu a permanência da ondem social africana. 0 surgimento dos candomblés espelharia, então, a tentativa de reconstituição desta ordem. Nestas circunstâncias, seus adeptos, negros africanos e descendentes, participavam de dois universos: um, "africano", restrito ao mundo dos candomblés e, estes, formando um casulo enquistado na sociedade abrangente, "brasileira". Com isto, Bastide definiu a possibilidade de trânsito entre os dois universos através do "princípio de corte" e acreditava que no universo dos candomblés eram os valores religiosos que "segregavam as estruturas" moldando sua base morfológica. Daí a enorme importância que, sob esta ótica, adquiriram os estudos etnográficos de tereiros de candomblé baianos, que em geral enfatizaram aspectos tradicionais da religião africana e, portanto, serviram de demonstração empírica para a argumentação da sobreposição do domínio do sagrado sobre as outras esferas sociais (BASTIDE, 1985: 225).

No sudeste, ao contrário, devido às transformações capitalistas da infra-estrutura econômica e social que impôs frmas específicas de inserção dos negros e seus descendentes na estrutura de classes, e não permitiu o enquistamento destes em redes de sociabilidade nos moldes do candomblé baiano, o sagrado sofreu a pressão de um estilo de vida mais apegado ao individualismo, a que corresponderia à integração desfavorável do negro desamparado nas grandes cidades. Nestas circunstâncias, a religião africana "se transformou" em magia e o espírito comunitário do candomblé teria se esfacelado, num primeiro momento, em expressões religiosas menos "orgânicas" como a macumba urbana, para posteriormente se organizar na forma do espiritismo de umbanda. 
Nas palavras de Bastide, a macumba urbana é então,

Esse mínimo de unidade cultural necessário à solidariedade dos homens em face de um mundo que não lhes traz senão insegurança, desordem e mobilidade. Se se prefere, ela é o reflexo da cidade em transição, na qual os antigos valores desaparecem sem que os substituíssem os valores do mundo moderno [...]. A macumba é a expressão daquilo em que se tornam as religiões africanas no período de perda dos valores tradicionais; o espiritismo de Umbanda, ao contrário, reflete o momento da reorganização em novas bases, de acordo com os novos sentimentos dos negros proletarizados, daquilo que a macumba ainda deixou subsistir da África nativa (BA STIDE, 1985: 407). ${ }^{7}$

No caso das macumbas rurais, estas teriam resultado da dispersão do negro na estrutura social agrária brasileira onde, pela falta de grupos estruturados, a memória coletiva não pôde funcionar, ocasionando a perda de rituais e a absorção da influência da cultura cabocla. Nestas condições, o alto se desenvolveu ao redor de certos indivíduos macumbeiros, curadores, benzedores e médiuns.

O sincretismo presente na macumba surge, assim, nos quadros dos processos aculturativos que presidem a vida associativa na cidade; contudo, para Bastide, a aculturação só poderia agir quando as representações coletivas autorizassem a sua possibilidade. Nesse sentido, sua explicação deveria ser buscada nas formas de classificação que representam a maneira de pensar de cada sistema religioso e a partir das quais são moldadas as coisas novas apresentadas pelo contato cultural. Nesta ótica existiriam tantos sincretismos quanto a natureza das representações coletivas e das coisas que são postas em contato.

Daí ser importante, na explicação deste fenômeno, a diferenciação utilizada pelo autor entre religião e magia. $\mathrm{Na}$ religião, o pensamento opera por analogias ou correspondências e a natureza do seu sincretismo não é de simples mistura ou identificação, porém de tradução onde as equivalências míticas permanecem estruturadas num sistema. Na magia prevalece a lei da acumulação ou adição. É aqui, portanto, que o fenômeno do sincretismo adquire caráter de fusão e síntese de elementos das mais variadas fontes com uma finalidade, sobretudo operacional, onde o que conta é a eficiência em atingir o objetivo da ação mágica que, em geral, se assentaria sob finalidades moralmente

\footnotetext{
$7 \mathrm{Ou}$, como sustentava Tullio Seppilli, que muito influenciou Bastide em suas análises da influência da cidade sobre a religiosidade africana: "Podemos em síntese afirmar que [...] a ruptura com os contatos com a África, a maior diferenciação social dos negros e mulatos, a modernização da vida social em torno de novos núcleos industriais e comerciais, a consequiente maior variedade de instâncias e contatos culturais (cultura rural e urbana de vários tipos, cultura das diversas levas de imigrantes) e ao mesmo tempo a quase ausência de uma linha de cor" entre os ex-escravos e o resto da população, foram a base de uma diferenciação e de uma aceleração de todos os processos de desagregação, de adaptação e de sincretismo, das antigas e já anteriormente modificadas culturas africanas" (SEPPILLI, 1955: 13).
} 
espúrias. E, para Bastide, é principalmente nas cidades do sudeste que este sincretismo poderá ser encontrado:

[...] a religião afro-brasileira tende, em algumas grandes cidades como Rio e São Paulo, devido à influência da desorganização urbana, a tomar, cada vez mais, um aspecto de magia, seja para o bem, seja para o mal. [...] A macumba do Rio é um exemplo frizante. Portanto,[...] por toda parte em que a religião africana tende a se manter como religião verdadeira, o sincretismo tem a forma de um sistema de correspondências classificadoras; por toda parte em que é magia, toma a forma de um sistema acumulador de elementos tomados a todos os cultos, mas desempenhando todos a mesma função, agindo todos segundo o mesmo principio de eficiência (BASTIDE, 1983: 191).

Indagará o francês sobre como seria possível entendermos o que levou ou leva as religiões africanas a se manterem como "religiões verdadeiras" em algumas cidades e "degradadas" em outras ou como seria possível que o candomblé tenha permanecido como meio de controle social, de solidariedade e comunhão enquanto a macumba tenha resultado no "parasitismo social, na exploração desavergonhada da credulidade das classes baixas ou no afrouxamento das tendências imorais, desde 0 estupro, até freqüentemente, 0 assassinato"? (Idem, 1985: 414).

Nos textos de Bastide, as respostas a estas questões surgem como resultado de elaborações teóricas dicotômicas não suficientemente justificadas (ou etnografadas), mas que nos remetem às diferenças entre degradação como desorganização cultural e degradação como desorganização social; fenômenos que, por sua vez, ocorrem de forma diversa se localizados no interior de um Brasil "arcaico", nordestino, comunitário, ou no Brasil "moderno" do sudeste, multirracial, de rápida evolução e que "repele para fora do novo Brasil todos quantos não podem acompanhar a velocidade desta evolução" (Ibid., 417).

A admiração do autor pelas formas consideradas mais preservadas da religião, como lhe pareceu encontrar nos candomblés baianos, no tambor de mina maranhense, nos xangôs pernambucanos e nos batuques gaúchos, o faz acreditar na força das tradições culturais diante de um mundo ainda preso pelos laços comunitários e, quando essas tradições se mostraram operantes através de opções diferenciadas de desenvolvimento, 0 autor julgou-as frágeis, como aliás já o fizera Arthur Ramos quando afirmava que o negro em si não tinha muita coisa a ver com a passagem do candomblé para as outras formas religiosas "menos orgânicas", pois aqui se trata do poder de desagregação social que vitimiza as suas tradições. 
Dois pesos e duas medidas explicam, portanto, as soluções teóricas bastidianas: quando o terreiro é um nicho altural incrustado na cidade, esta desaparece enquanto poder de determinação, sendo, portanto, desnecessário descrevê-la. Quando se ausenta a etnografia do terreiro - mas este é pressuposto mesmo sem contornos nítidos -, entram em cena as descrições da degeneração do mundo urbano modemo.

\section{Conclusão}

Todavia, este filão da crítica a Bastide, também parece desœnsiderar aspectos importantes das análises realizadas pelo francês sobre a estrutura do candomblé, do transe e do culto, diante do "pecado original" por ele cometido: a reafirmação do interesse pelo candomblé nagô.

É preciso lembrar ainda que na mesma década de 1970, quando se iniciam as críticas mencionadas, o próprio Bastide está repensando os seus modelos explicativos. Em 1971, no artigo "As contribuicões culturais dos africanos na América Latina: tentativa de síntese", ele descarta completamente a noção de sobrevivência para pensar as influências africanas nas Américas e propõe uma redefinição da agenda de pesquisas sobre cultura afro-brasileira: ao invés de sublinhar permanências africanas cristalizadas, sendo necessário acompanhar de perto a emergência de novos processos.

É nessa linha, ainda inexplorada, que seria preciso prosseguir para descobrir a contribuição da África para a cultura (ou para as duas culturas) da A mérica Latina enquanto culturas vivas e criadoras, e não enquanto conservação de africanismos enquistados (Q UEIROZ, 1983: 167).

É possível localizar um progressivo afastamento de Bastide em relação à busca de africanismos em solo brasileiro (e americano) a partir da década de 1970 e, portanto, um progressivo afastamento da tradição africana local, até do ponto de vista temático. Em seus últimos ensaios, ele é cada vez mais insistente em relação à necessidade de melhores análises do sincretismo religioso em suas formas originais. Impressionado pelo sucesso crescente da umbanda no Brasil, por exemplo, ele alerta os sociólogos e antropólogos para a importância dessa religião, chamando-os a saírem da condenação do fenômeno e passarem à sua análise (BASTIDE 1975: pp. 45-52). Em 1974, reafirma:

A antropologia cultural não pode permanecer hipnotizada pelo mundo candomblé, ou pela sua fidelidade à cultura ancestral. As religiões afro-brasileiras são religiões vivas que para sobreviver adaptam-se às novas estruturas sócioeconômicas brasileiras e a outras metamorfoses, dando origem a novas formas: 
primeiro a macumba e, acima de tudo, o espiritismo de umbanda (Idem, 1974: 188).

Na última fase de sua obra, o que parece despertar a atenção do intérprete é a plasticidade do culto afro-brasileiro e o processo sincrético que tem lugar inclusive nos seio do candomblé mais tradicional. Em "La Rencontre des Dieux Africains et des espirits indiens" (1973), analisa a presença do cabloco nos candomblés, observando que apesar da vontade explícita de seus membros em permanecerem africanos, antes de qualquer outra coisa eles são "brasileiros, patriotas e nacionalistas" (Idem, 1975: 188).

Posto isto, cremos que seríamos mais fiéis a Bastide se falássemos em diálogo do autor com a tradição africanista nacional, do que em relação de pura continuidade. ${ }^{8}$ Além disso, para que as idéias do autor sejam melhores avaliadas faz-se necessário incluir 0 referido diálogo numa série mais ampla. Claro está, que os leitores-críticos de Bastide aqui referidos estão interessados na compreensão do fenômeno religioso e não acompanhar os meandros de seu pensamento. É neste sentido que recortam uma parte de sua vasta obra, 0 que manifesta riscos envolvidos - os quais correspondem a uma fase determinada dos estudos de Bastide sobre religião - e na generalização destas interpretações.

Ao situarmos estes estudos no tempo e num contexto expandido, vemos não ser exato supor uma visão negativa de Bastide em relação ao sincretismo, como sublinha as leituras críticas, como se a busca da "pureza" e da "autenticidade" implicasse numa desvalorização necessária dos produtos sincréticos, revelada pelas oposições candomblé/ umbanda, religião verdadeira/ magia degenerada. Se ele opera com a pureza como modelo e em alguns momentos mostra-se nostálgico em relação à África perdida, ou nunca encontrada completamente no Brasil, de modo geral, o sincretismo é lido como sinônimo de vitalidade da tradição africana e, o que é mais importante, a interpretação de civilizações sinonimiza o autenticamente nacional.

As preocupações de Bastide com a religião têm lugar em um cenário alargado. Duglas Monteiro, por exemplo, aponta nesta direção quando afirma que os trabalhos de Bastide sobre religião devem ser pensados nas raízes de suas reflexões sobre o contexto multi-racial brasileiro, no interior de uma sociologia das relações interétnicas, ou seja, no contexto de uma reflexão mais ampla sobre a sociedade brasileira. A religião é uma via de

${ }^{8}$ Diálogo, na acepção da palavra, remete à troca de idéias, à comunicação, e não à simples concordância (neste caso, mais próximo estańamos do monólogo). 
acesso, entre outras, para a compreensão do Brasil. Via que, se percorrida, aproxima-nos da porção africana dessa sociedade.

Bastide se debruça sobre o fenômeno religioso para compreendê-lo, é evidente, mas também para ter acesso à África, preocupação já anunciada em seus primeiros trabalhos sobre a arte nacional. ${ }^{9}$ Mas encontrar a África não significa se contentar com 0 seu registro. E olhar a África no Brasil implica obrigatoriamente o movimento inverso: olhar o Brasil sincrético a partir da África, já que sem o termo africano torna impossível pensar o país.

\section{Bibliografia}

1. ABRAHAM, R. C. Didionary of modan Youba Londres: University of London Press. 1958.

2. ALVES VELHO, Y. M. Guera deOnixás Rio de Janeiro: Zahar, 1975.

3. BASTIDE, Roger. As Reigiões Africanas mo Brasil: Contribuição para uma Socidoga das Intependraç̃es deCivilizaçóes Vols. I \& II, São Paulo: Livraria Pioneira Editora, 1985.

$4 . \quad$. ImagensdoNardesteMísticoemBrancoePreto Rio de Janeiro: O Cruzeiro, 1945.

5. . EstudosAfroBrasileiros São Paulo: Perspectiva, 1983.

6. ThePrent Status of Afroamerican rearchin LatinAmeria, D aedalus, vol. 103, no $\overline{2}, \overline{1} \overline{7} \overline{4}$.

$7 . \quad$. "L'umbanda em revision". In: Études offets à Jacques Lambet Paris: Éditions Cujas, $197 \overline{5}$, pp. 45-52.

$8 . \quad$. O Candonbléda Bahia: nitonagâ São Paulo: Companhia Editora Nacional, 1958.

9. - -

10. BENISTE, José. OnumAiye oencontrodedaismmoss o sistema derdacionamentonagôianub́ etre oću ea tera. Rio de Janeiro: Bertrand Brasil. 1997.

11. BRAGA, Julio. "Ifá no Brasil”. In: Reista das Ciênaas Humanas Salvador: UFBa/ FFCH. n. 1. p. 113 - 122.jul. 1980.

12. _. Na Gamda do Fètiça reqressão e resistênia nos candomblés da Bahia Salvador: EDUFBa.1995.

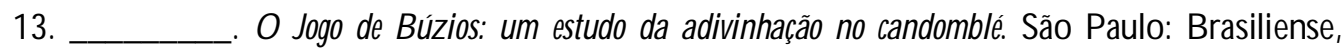
$19 \overline{8}$.

14. $\overline{1} \overline{9} \bar{q} \overline{.}$ . Anrestralidade Afrobrasilera: o alto de baba Egum Salvador: CEA O/ Ianamá,

15. CACCIATORE, Olga Gudolle. Diainánio de altos afrobrasileiros Rio de Janeiro: Editora Forense Universitánia, 1977.

16. CARNEIRO, Édison. Negos Bantos Rio de Janeiro: Civilização Brasileira, 1981 ạ

17. _. Reigõoes Negras Rio de Janeiro: Civilização Brasileira, 1981b

18. $\mathrm{CASTRO}$, Yeda Pessoa de. "Língua e nação de candomblé". ln: ÁFRICA. Revista do Centro de Estudos Africanos. USP. 4, 1981.

\footnotetext{
${ }^{9}$ A literatura em geral e a poesia em particular foram matéria preferencial de atenção do sociólogo Bastide. No que se refere à produção sobre o Brasil, Bastide foi um leitor cuidadoso. Escreveu sobre autores consagrados: Machado de Assis, José de Alencar; comentou a produção modernista, Mário e Oswaldo de Andrade; não esqueceu a geração de 30: Drummond, Bandeira; interferiu no debate da época resenhando livros recém lançados. José Lins do Rego, Graciliano Ramos, Clarice Lispector, Orígenes Lessa, Augusto Frederico Schmidt e uma infinidade de outros nomes conheceram sua crítica.
} 
19. DANTAS. Beatriz Góis. "A Pureza e poder rio mundo dos Candomblés". In: MOURA, Carlos Eugênio Marcondes de (O rg.). Candonblé DestendandbIdantidades Novos æartos sobrea redigãodos anixás São Paulo: EMW Editores. 1987.

20. . VowóNaĝ̣ePapai Branco Rio de Janeiro: Graal, 1988.

21. FRY, Peter. Fëjcada eSaul-Food In: Para IndêêsVe. Rio de Janeiro: Zahar, 1982, pp. 47-53.

$22 . \quad$. Galiusaficanus et a comb Bastidesetoma aficanonoBrasil. In: O lga Von Simson (org.). ReisitandoTera deContrastes São Paulo: FFLCH/ CERU, 1986, pp. 31-46.

23. $19 \overline{9} \overline{6}$. . \& VO GT, Carlos. Cafundó - A África no Brasil. São Paulo: Cia. Das Letras,

24. JOHNSO N. Samuel. Thehistary of the Ionubas from the Earliet Times to the Begining of Bitish Protetorate Lagos, Nigéria: Bookshops. 1937.

25. LIMA. Vivaldo da Costa. "O s obás de xangô". In: AFRO-ASIA. Salvador: CEAO n.2-3. p. 5-36.1966.

26. Salvador: ĊEAO . n. 12, pp. 65-90, 1978.

$27 . \quad$ A famíliadesantonos candonblésjejenagôs da Bahia: umestudbderdações intragrupais Salvador-Bahia: Pós-Graduação em Ciências Humanas da UFBA, 1977.

28. MAGNANI, José Cantor. Umbanda São Paulo: Editora Ática, 1986.

29. MATTOS, Dalmo Belford de. "As Macumbas em São Paulo". In: Reista do Arquivo Muniđipal. São Paulo: Ano V, vol. XLIX, 1938.

30. MONTEIRO, D uglas Teixeira. "Roger Bastide: religião e Ideologia”. In: RdigãoeSociedade, Rio de Janeiro: Civilização Brasileira, no 3, 1978.

31. NEGRÃO, Lísias Nogueira. Entrea đuz ea enmuillhada São Paulo: EDUSP, 1996.

32. _ "A Umbanda como expressão de religiosidade popular". In: Reigãa esociedade, n. 4, Rio de Janeiro: Civilização Brasileira, out. 1979.

33. ___ "O processo de cura nos cultos afro-brasileiros". In: Ciênias da Reigãa 1. A vida emmioà motenumpaís do TexeiroMunda São Paulo: Paulinas, 1983.

$34 . \quad$.Roger Bastide: do Candomblé à Umbanda". In: Revisitandba Tera decontrastes a atualidädeda dara deRogr Bastide São Paulo: USP-FFCHL / CERU, 1986.

35. . "A Construção sincrética de uma identidade". In: Ciênaias Scaiais Hgje $\overline{\mathrm{A}} \overline{\mathrm{N}} \overline{\mathrm{P}} \mathrm{O} \overline{\mathrm{C}} \mathrm{S}-\mathrm{CNPq}, 1991$.

$36 . \quad$ _ \&CONCO NE, Maria Helena V. B. "Umbanda: da repressão à cooptação: 0 envolvimento político-partidário da Umbanda paulista nas eleições de 1982". In: Unbanda e pdítica Rio de Janeiro, ISER / Marco Zero, 1985.

37. PRAND I, Reginaldo. Oscandonbés deSãoPaula São Paulo: Hucitec/ ED USP, 1991.

38. QUERINO, Manuel. Costumes afiicanosmoBrasil Recife: FUNDAJ Massagana,1988.

39. Q UEIROZ, Maria Isaura P. (org.). Rogr Bastide São Paulo: Ática, 1983.

40. RAMOS, Arthur. O NegroBrasilera São Paulo: Nacional, 1940.

41. REGINALDO, Lucilene. "Uns três Congos e Alguns Angolas: a construção da 'invisibilidade' dos 'Bantos' na Bahia". Paper da Tese de Doutorado - Experiênáas e Idantidades immandades deafricanos eciaulos noreêncavoda Bahia (1810-1860), UNICAMP, 2004.

42. RODRIG UES. Nina. OsaficanosmoBrasil. São Paulo: Companhia Editora Nacional. 1935.

43. SEPPILLI, Tullio. "A aculturação como Problema Metodológico". In: Atas da XLV Remião da SocieladeItaliama para o Progesso da Ciênaia (Nápoles, 1954). Roma, Tip.Editrice. Tradução Lucy Maffei. IELI USP (mimeo), 1955.

44. SERRA, O rdep. ÁguasdoRè. Petrópolis: Vozes, 1995.

45. SIMSON, Olga von (org.). RexistantoTera deContraste São Paulo: FFLCH/ CERU, 1986.

46. VERGER, Pierre. Orixás Dases Iđubás na África e no Nowo Mundo Salvador: Corrupio, 1981/ 1997. 